\title{
Effect of Plant Growth Regulators on Growth and Flower Yield of Jasmine (Jasminum nitidum) c.v CO-1 (Star Jasmine)
}

\author{
T. Chandra Sekhar*, S. S. Saravanan and S. Sreethu \\ Department of Horticulture, Naini Agricultural Institute, SHUATS, \\ Prayagraj, Uttar Pradesh 211007, India \\ *Corresponding author
}

\begin{abstract}
A B S T R A C T
\section{Keywords}

Cycocel, $\mathrm{GA}_{3}, \mathrm{MH}$, NAA, Star Jasmine

Article Info

Accepted:

26 August 2020

Available Online:

10 September 2020

A study was conducted in Floriculture Unit of the Department of Horticulture, Naini Agriculture Institute, SHUATS, Prayagraj during 2019-20 to evaluate the growth, flowering and yield of Jasminum nitidum c.v CO-1(Star Jasmine) with the effects of four growth regulators namely Naphthalene acetic acid (NAA), Gibberellic acid $\left(\mathrm{GA}_{3}\right)$, Cycocel and Maleic hydrazide $(\mathrm{MH})$ each at 3 concentrations. The experiment comprised of 13 treatments, T1-Control (water spray), T2-NAA(25ppm), T3-NAA(50ppm), T4-NAA (75 ppm), T5-GA 3 (25ppm), T6-GA 3 (50ppm), T7-GA 3 (75ppm), T8-CCC (500ppm), T9CCC (750ppm), T10-CCC (1000ppm), T11-MH (100ppm), T12-MH (200ppm), T13$\mathrm{MH}(250 \mathrm{ppm})$, and was laid out in Randomized Block Design and replicated thrice. The results were revealed that plant height with $80 \mathrm{~cm}$ was superior at GA3 $75 \mathrm{ppm}$ concentration over rest of the treatments. Cycocel at $750 \mathrm{ppm}$ and $\mathrm{MH}$ at $250 \mathrm{ppm}$ were equally effective in increasing the plant spread in $\mathrm{N}-\mathrm{S}(47.7 \mathrm{~cm})$ and $\mathrm{E}-\mathrm{W}(46.3 \mathrm{~cm})$ and closely followed by NAA at $75 \mathrm{ppm}(47.7 \mathrm{~cm}$ and $41.7 \mathrm{~cm}) . \mathrm{MH}$ at $250 \mathrm{ppm}$ increased number of primary branches per plant (5.7) followed by NAA at $75 \mathrm{ppm}$. MH at 200ppm significantly increased secondary branches per plant (11.3) followed by $\mathrm{GA}_{3}$ at $75 \mathrm{ppm}$. Cycocel at $1000 \mathrm{ppm}$ induced early flowering (78.67 days) followed by $\mathrm{GA}_{3}$ at $75 \mathrm{ppm}$ and $\mathrm{MH}$ at $250 \mathrm{ppm}$ with 80 days.MH significantly increased flower yield $(2.03 \mathrm{~kg} / \mathrm{plant} / \mathrm{year})$ at $250 \mathrm{ppm}$.Based on these studies, it can be recommended that primary branches and flower yield can be increased by spraying of $\mathrm{MH}$ at 250ppm in Jasminum nitidum c.v CO1 (star jasmine).
\end{abstract}

\section{Introduction}

Jasmine is one of the oldest of fragrant flowers and is specially appreciated in India, where most people have a love for the fragrant flowers. The word Jasmine has been derived from Persian word. 'Yasmyn' meaning fragrance since time immemorial, it is considered as a spiritual flower of India. Jasmine is considered as the "King of Oils" (Rose is the "Queen") especially for its flowers and sweet fragrance. A single jasmine vine can perfume an entire room or garden. India is one of the centers of origin of jasmine. For the past many centuries jasmines have adorned the gardens of Central 
and South East Asia, Afghanistan, Iran, Nepal and many other tropical and subtropical countries and many of the jasmine species are native of India and have their origin in the Southern Foothills of the Himalayas.

The jasmine belongs to family 'Oleaceae' and the Genus Jasminum comprises of about 500 species, which are dispersed in the warmer parts of Europe, Asia, Africa and the Pacific region (Bhattacharjee, 1980). A critical analysis of these species, however, has revealed the number of true species to be only 89 , of which 40 inhabit the Indian subcontinent.

Recently, jasmine cultivation has received a fillip through research findings which indicated the potentiality of South Indian Jasmine. But one of the serious limiting factors which affects both jasmine flower growers and the consumers and which is likely to affect commercial production, is that the flowering of all the Jasminum species is seasonal. There are peak and lean productive seasons with consequent gluts and scarcity which affect the price trends greatly.

Tamil Nadu Agriculture University (TNAU) newly-released CO-1 Star jasmine (Jasminum nitidum), which promises flower throughout the year as an alternate to the traditional jathi malli. A main stay in temple rituals, jathi malli becomes expensive and unavailable during winter (between November and February) because it is off season for the variety. To address the issue, TNAU developed the new variety of jasmine, which will flower throughout the year especially in the lean season (Nov-Feb). Jasminum nitidum c.v CO-1(star jasmine) is an evergreen and bears dual characteristics, it acts like a shrub when planted alone and can be pruned to desired shape to act like a ground cover, as well as like a twining vine (semi-climber) and climbs using tendrils or twines when planted near a support, reading up to 3-4 feet as shrub alone and can climb up to 20 feet as a vine. It has a fast-growing habit and can be used as indoor plant too.

The plants, have long woody stem and bold buds with pinkish tinge, which blooms into snow white star shaped flower with 10 petals which are leaner, longer and spread out. The flower bears a mild pleasing scent and appears in cluster forms (inflorescence) with slaver form shape (tubular base and open flat petals). The flowers bloom at night and easy to pluck, with its long stem and bold buds, it is easier to string them too. The flowers will not droop for four to five hours. The buds, after plucking and even stringing, remain unopened for 12 hours under room temperature and could remain so for 60 hours under refrigeration. Leaves are smooth, leathery, simple (not divided), lanceolate (broad at center) with opposite arrangement and dark glossy green which in addition makes the plant attractive.

Developments after the discovery of growth regulators and their application in agriculture and more especially in horticulture are significant. Regulation of plant growth and development using natural plant hormones for greater production have received the utmost attention (Leetham et al., 1978). Growth and flowering responses of ornamental plant to these chemical substances have been intensively studied with a view to have compact plants with greater number of flowers and also to hasten or delay flowering according to the needs of the grower (Cathey, 1980).

The term "Plant Growth Regulators" was proposed by Tukey et al., (1954) to include natural and artificial compounds. They are defined as organic compounds other than nutrients, which in small amounts promote, 
inhibit or otherwise modify any physiological process in plants. The key uses of plant growth regulators in ornamental horticulture and floriculture include regulation of plant height, profusion of branching, propagation of cuttings, control of flowering, enhancing stress tolerance, increasing post-harvest longevity during shipping, storing and marketing besides increasing the display of flowers and potted plants. These hormones are defined as organic compounds, other than nutrients, produced by plants in minute quantities, which in low concentration regulate namely, promote, inhibit or otherwise modify different phases of plant growth and development.

Hence the paper deals with the effect of plant growth regulators on growth and flower yield of jasmine (Jasminum nitidum) c.v co-1 (Star jasmine) with the aim to include foliar application of those on a new variety of jasmine in order to know its positive effect on productive and economical yield aspects.

\section{Materials and Methods}

The present investigation was carried out in form of a field experiment in the garden of the Department of Horticulture, Naini Agricultural Institute, Sam Higginbottom University of Agriculture, Technology and Sciences, Prayagraj, Uttar Pradesh, India during 2019-20. This area is situated on the right side of the Yamuna River by the side of Prayagraj-Rewa road about $12 \mathrm{~km}$ from the city. Prayagraj has a subtropical and semiarid climatic condition, south-eastern part of Uttar Pradesh prevails with both extremes of temperature, i.e. in winter, during December and January temperatures sometime fall very low up to $3^{\circ} \mathrm{C}$, while the weather becomes very hot in summer with the temperatures sometimes soaring to a high of over $48^{\circ} \mathrm{C}$ in May and June.
The soils were characterized as sandy loam in texture with $\mathrm{pH} 7.3$ analyzed using glass electrode $\mathrm{pH}$ meter, electrical conductivity $0.30 \mathrm{dS} / \mathrm{m}$ analyzed using conductivity meter (Jackson, 1973), organic carbon $0.55 \%$ Walkley and Black method (Nelson and Sommer, 1982), available N $261.725 \mathrm{~kg} / \mathrm{ha}$ Alkaline potassium permanganate method for nitrogen (Subbiah and Assija, 1956), available P $18.4 \mathrm{~kg} / \mathrm{ha}$ analyzed by Olsen's method (Nelson and Sommer, 1982), available K $251.6 \mathrm{~kg} / \mathrm{ha}$ analyzed by Flame photometry (Jackson, 1973).

The experiment was laid out in Randomized Block Design. There were 13 treatments and each replicated thrice. Treatments were allocated randomly to each replication. T1Control (water spray), T2-NAA (25ppm), T3NAA (50ppm), T4-NAA (75 ppm), T5- GA 3 (25ppm), T6- $\mathrm{GA}_{3}$ (50ppm), T7-GA $_{3}$ (75ppm), T8-CCC (500ppm), T9-CCC (750ppm), T10-CCC (1000ppm), T11-MH (100ppm), T12-MH (200ppm), T13-MH (250ppm).

For growth attributes, the height of plant was measured from the base of the plant to the highest point of the uppermost leaf and expressed in centimeter, Number of primary branches and secondary branches per plant are counted, Plant spread from north to south and east to west are measured and expressed in centimeters. The observations were recorded at 30 days intervals from planting to harvesting of flower buds.

For yield attributes, the number of days taken for flower bud initiation was recorded by counting the days, the number of flower buds per plant was counted and average numbers of flower buds were recorded, the yield of flowers per plant is weighed daily and calculated per year and converted it into tonnes/hectare per year. 
The data from the experiments were analyzed statistically, wherever treatment differences were found significant, the critical differences were worked out at $5 \%$ level of probability $(P=0.05)$.

\section{Results and Discussion}

\section{Growth parameters}

The highest plant height was observed with the application of $\mathrm{GA}_{3}-75 \mathrm{PPM}(80.00 \mathrm{~cm})$ which was significantly superior over control $(32.70 \mathrm{~cm})$ (Table 1). The PGR'S when applied as foliar spray were absorbed by the leaves and readily translocated in both xylem and phloem tissues resulting in distribution throughout the plant system. This might be the reason for the enhancement in plant height. $\mathrm{GA}_{3}$ can affect plant growth by its effect on cell growth and cell elongation leading to bigger plants.

The number of primary branches were found to be significant among the treatment. The maximum numbers of primary branches (5.7) were recorded in treatment with $\mathrm{MH} 250$ $\mathrm{ppm}$. The highest secondary branches were observed with the application MH 200ppm $(11.30 \mathrm{~cm})$ which was significantly superior over control $(6.00 \mathrm{~cm})$ (Table 1). Effect of MH significantly decreased plant height and intermodal length, increased plant spread, number of branches. $\mathrm{MH}$ probably interfered with metabolic activities of the plant by intercepting nutrient assimilation and growth.

Table.1 Effect of Plant Growth Regulators on Growth Parameters of Jasmine (Jasminum nitidum) c.v CO-1 (Star Jasmine)

\begin{tabular}{|c|c|c|c|c|c|}
\hline TREATMENTS & $\begin{array}{l}\text { PLANT } \\
\text { HEIGHT } \\
\text { (cm) }\end{array}$ & $\begin{array}{c}\text { PRIMARY } \\
\text { BRANCHES } \\
\text { (no.) }\end{array}$ & $\begin{array}{c}\text { SECONDARY } \\
\text { BRANCHES } \\
\text { (no.) }\end{array}$ & $\begin{array}{c}\text { PLANT } \\
\text { SPREAD } \\
(\mathrm{N}-\mathrm{S})(\mathrm{cm})\end{array}$ & $\begin{array}{c}\text { PLANT } \\
\text { SPREAD } \\
(\text { E-W) }(\mathbf{c m})\end{array}$ \\
\hline CONTROL & 32.7 & 2.7 & 6.0 & 24.3 & 26.0 \\
\hline NAA - 25 PPM & 26.7 & 2.3 & 4.7 & 41.3 & 40.7 \\
\hline NAA - 50 PPM & 44.8 & 3.7 & 7.3 & 36.7 & 36.0 \\
\hline NAA - 75 PPM & 47.9 & 5.0 & 6.0 & 47.7 & 41.7 \\
\hline $\mathbf{G A}_{3}-25$ PPM & 27.0 & 1.7 & 1.7 & 17.7 & 29.0 \\
\hline $\mathrm{GA}_{3}-50$ PPM & 52.0 & 4.7 & 7.7 & 42.0 & 37.3 \\
\hline $\mathrm{GA}_{3}-75$ PPM & 80.0 & 4.3 & 11.0 & 38.3 & 30.7 \\
\hline CCC - 500 PPM & 33.7 & 4.7 & 6.7 & 35.0 & 31.8 \\
\hline CCC - 750 PPM & 53.3 & 4.3 & 8.3 & 47.7 & 45.7 \\
\hline CCC - 1000 PPM & 36.0 & 2.7 & 6.7 & 30.7 & 34.7 \\
\hline MH - 100 PPM & 41.0 & 4.0 & 11.0 & 42.0 & 32.7 \\
\hline MH - 200 PPM & 29.3 & 4.0 & 11.3 & 28.7 & 32.7 \\
\hline MH - 250 PPM & 53.3 & 5.7 & 10.7 & 47.3 & 46.3 \\
\hline F-test & $\mathrm{S}$ & S & S & $\mathrm{S}$ & $\mathrm{S}$ \\
\hline S.Em \pm & 8.51 & 0.78 & 1.86 & 6.06 & 4.18 \\
\hline CD (0.05) & 24.85 & 2.27 & 5.42 & 17.68 & 12.21 \\
\hline
\end{tabular}


Table.2 Effect of Plant Growth Regulators on Yield Parameters of Jasmine (Jasminum nitidum) c.v CO-1 (Star Jasmine)

\begin{tabular}{|c|c|c|c|c|}
\hline TREATMENTS & $\begin{array}{c}\text { DAYS TO BUD } \\
\text { APPERANCE }\end{array}$ & $\begin{array}{c}\text { NUMBER OF } \\
\text { FLOWERS PER PLANT }\end{array}$ & Kg/Plant/Year & T/ha/year \\
\hline CONTROL & 118.00 & 354.09 & 0.85 & 3.78 \\
\hline NAA - 25 PPM & 91.67 & 476.63 & 1.14 & 5.08 \\
\hline NAA - 50 PPM & 92.67 & 569.47 & 1.37 & 6.07 \\
\hline NAA - 75 PPM & 86.67 & 577.67 & 1.39 & 6.16 \\
\hline GA - 25 PPM & 91.67 & 388.53 & 0.93 & 4.14 \\
\hline GA $_{3}$ - 50 PPM & 96.00 & 436.56 & 1.05 & 4.66 \\
\hline GA3 - 75 PPM & 80.00 & 811.20 & 1.95 & 8.65 \\
\hline CCC - 500 PPM & 88.00 & 464.51 & 1.11 & 4.95 \\
\hline CCC - 750 PPM & 89.67 & 463.32 & 1.11 & 4.94 \\
\hline CCC - 1000 PPM & $\mathbf{7 8 . 6 7}$ & 671.69 & 1.61 & 7.16 \\
\hline MH - 100 PPM & 98.33 & 451.39 & 1.08 & 4.81 \\
\hline MH - 200 PPM & 88.00 & 608.35 & 1.46 & 6.49 \\
\hline MH - 250 PPM & 80.00 & $\mathbf{8 4 7 . 7 2}$ & $\mathbf{2 . 0 3}$ & $\mathbf{9 . 0 4}$ \\
\hline F-test & S & S & S & S \\
\hline S.Em \pm & 6.80 & 80.83 & 0.19 & 0.86 \\
\hline CD (0.05) & 19.84 & 235.91 & 0.57 & 2.52 \\
\hline
\end{tabular}

Fig.1

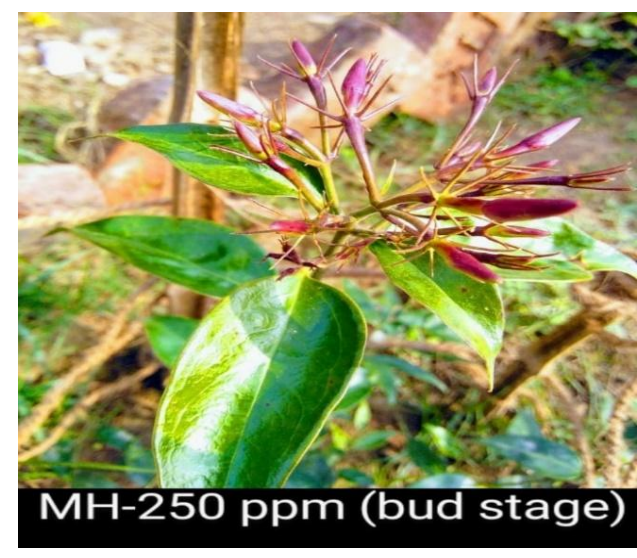

The highest plant spread (N-S) was observed with the application of NAA- $75 \mathrm{ppm}$ and CCC 750 ppm $(47.7 \mathrm{~cm})$ which was significantly superior over control $(24.3 \mathrm{~cm})$ by $96.2 \%$ (Table 1). Auxin is probably investigated plant hormone and to be involve in virtually in every aspect of plant growth

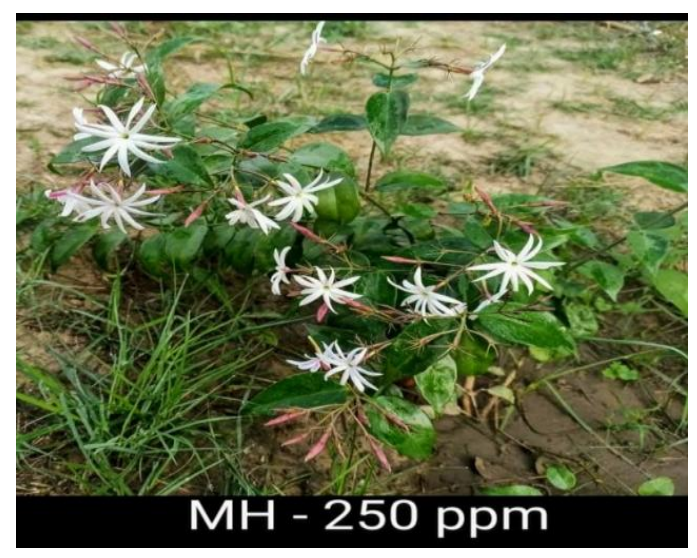

and development. Auxin group NAA increases the growth of the plants by cell division, cell elongation apical dominance. The highest plant spread (E-W) was observed with the application of $\mathrm{MH} 250 \mathrm{ppm}$ (46.3) which was significantly superior over control $(26.00 \mathrm{~cm})$ by $78 \%$ (Table 1$)$. 


\section{Yield parameters}

Early flowering was observed with CCC 1000 ppm (78.67 days) that is 39.33 days earlier than control which obtained flowering at 118 days, this might be due to anti -gibberellin action of CCC.

Highest number of flowers (847.72) and yield per plant $(2.03 \mathrm{~kg} /$ plant/year $)$, per hectare $(9.04$ $\mathrm{t} / \mathrm{ha} /$ year) was observed in $\mathrm{MH} 250 \mathrm{ppm}$ which is superiorly higher over control by $139.4 \%$ (354.09, $\quad 0.85 \mathrm{~kg} / \mathrm{plant} /$ year, $\quad 3.78 \mathrm{t} / \mathrm{ha} /$ year) (Table 2).This might be due to more number of branching.

\section{References}

Bhattacharjee, S. K. (1980). Native Jasmine of India. Indian Perfumer, 24(3): 126- 133.

Cathey, M. H., 1980, Phosphon and CCC for controlling height of chrysanthemum. Floriculture Ex., 135: 12-13.

Gowda, J. V. N.; Venkate Gowda; Nage Gowda; Farooqi, A. A.;Bhattacharyya, S. C.;.1990; Effect of growth regulators on growth, flowering and composition in gundumallige(Jasminum sambac Ait.). Proceedings of the 11th international congress of essential oils, fragrances and flavours. New Delhi, India, 12-16 November, 1989. Vol. 3, 1990 pp. 105-112.

Gowda, V. N.; Gowda, J. V. N., 1990, Effect of Cycocel and maleic hydrazide on the biochemical composition in Gundumallige (Jasminum sambac Ait.).; Indian Perfumer, Vol. 34(4), pp. 238-242.

Jackson, M. L. 1973.Soil chemical Analysis prentice Hall of India. Pvt. Ltd. New Delhi: p. 498.

Leetham, D. S., Goodwing, P. B. and Higgins, T. J. V., 1978, Phytohormones and related components: A comprehensive treatise Vol.
2, Elsevier, Amsterdam

Neha Chopde, Amruta Pawar, VU Raut and Bhavishya Nikam, 2017, Response of Jasminum sambac L. to plant growth retardants, International Journal of Chemical Studies 2017; 5(6): 608-610.

Nelson, D. W. and Sommers, L. E. 1982. Total casrbon, organic carbon and organic matter in: Methods of Soil Analysis Part-II. Page. A.L. (Ed), Am. Soc. Agron. Inc. Soil Sci. Soc. Am. Madism.pp. 539- 577.

Sudhagar, R., S. Kamalakannan, 2017, growth retardants effects on flowering and yield parameters of spanish jasmine (Jasminum grandiflorum L.), Journal of Floriculture and Landscaping 2017, 3(01-03)

Sharifuzzaman S.M, K.A. Ara, M.H. Rahman, K. Kabirand M.B. Talukdar (2011), Effect of $\mathrm{GA}_{3}, \mathrm{CCC}$ and $\mathrm{MH}$ on Vegetative Growth, Flower Yield and Quality of Chrysanthemum, International journal of experimental agriculture. 2(1):17-20.

Shri Prakash, A.K. Singh, Mohit Kumar, and Balveer Singh, (2015), Effect of Plant Growth Regulators on Growth and Flowering Behavior of Chrysanthemum (Dendranthema grandiflora L.) cv. VASANTIKA. Annals of Plant and Soil Research 17 (Special Issue): 23-24.

Sobhana A (2014). Effect of bioregulators and cow's urine on flower production in jasmine (Jasminum sambac), The Asian Journal of Horticulture. 9(1):160-163.

Subbiahs, B. V. and Assija, G. L. 1956. A rapid procedure for the estimation of available nitrogen in soil. Current Sci., 25(8): 259260.

Vikas Kumar S, V.M.Prasad, S.Saravanan (2017), Effect of Plant Growth Regulators on Plant Growth and Flower Yield of Dahlia (Dahlia Variabilis L.). Cv. Suryodya, The Allahabad Farmer, Vol. LXXIII.

\section{How to cite this article:}

Chandra Sekhar, T., S. S. Saravanan and Sreethu, S. 2020. Effect of Plant Growth Regulators on Growth and Flower Yield of Jasmine (Jasminum nitidum) c.v CO-1 (Star Jasmine). Int.J.Curr.Microbiol.App.Sci. 9(09): 3587-3592. doi: https://doi.org/10.20546/ijcmas.2020.909.443 